\title{
Cytogenetic investigations of solid tumours of children
}

\author{
A D J PEARSON,${ }^{*}$ M M REID $†$ E V DAVISON $₫ \mathrm{~N}$ BOWN, A J MALCOLM,§ AND A W CRAFT* \\ ${ }^{*}$ Departments of Child Health and $\ddagger$ Human Genetics, University of Newcastle upon Tyne, and Departments \\ of †Haematology and \$Pathology, Royal Victoria Infirmary, Newcastle upon Tyne
}

SUMMARY The association of non-random chromosome abnormalities with solid tumours of childhood may improve accuracy of diagnosis and prognosis and lead to a better understanding of their biology. In a pilot study in the Northern region of England fresh tumour biopsy specimens were obtained from 39 of 72 consecutive solid tumours in children who presented over a period of 21 months. Cytogenetic analysis was possible in 33 and clonal chromosomal abnormalities were detected in nine. In addition, seven of 10 tumours investigated after treatment were abnormal. Ten of these 16 abnormal karyotypes have not previously been described. This pilot study has shown that a concerted investigation of tumour cytogenetics is possible. A multicentre study is essential if our knowledge of basic tumour cytogenetics is to progress.

Despite our ability to achieve prolonged remissions in most children with cancer, malignant disease remains second only to birth defects as the most common non-accidental cause of death in children over the age of 1 year in the United Kingdom. Accurate diagnosis is essential in order that appropriate treatment is used, but even within any one tumour category there remain variations in behaviour and response to treatment.

In the leukaemias some clonal cytogenetic abnormalities have already proved to be of diagnostic and prognostic value. For example, the translocations $\mathrm{t}(9 ; 22), \mathrm{t}(8 ; 21), \mathrm{t}(15 ; 17)$, and $\mathrm{t}(8 ; 14)$ help towards the diagnosis of chronic myeloid, acute myeloblastic, acute promyelocytic, and Burkitt's leukaemia respectively, ${ }^{1}$ and clonal structural abnormalities are associated with a poor outcome in acute lymphoblastic leukaemia of childhood. ${ }^{2}$ Studies of the oncogene c-abl in chronic myeloid leukaemia ${ }^{3}$ and the relationship between c-myc and immunoglobulin gene loci in Burkitt's lymphoma ${ }^{4}$ have led to a rapid increase in our knowledge of the molecular biology of haemopoietic malignancy.

Although clonal cytogenetic abnormalities have been reported in some solid tumours of children, much of the published information has appeared as single case reports. Cytogenetic investigations of solid tumours lag far behind those of leukaemias due to a combination of reasons including technical problems and the relative difficulty in obtaining viable tumour cells. One of the early steps in understanding the biology of malignancy, however, is to obtain a detailed knowledge of non-random chromosomal abnormalities of tumour cells. If the analogy with leukaemia is appropriate, then cytogenetic studies of solid tumours could provide diagnostic and prognostic information and the basis for a detailed study of the molecular events associated with their genesis.

In order that this baseline knowledge can be obtained a vigorous and comprehensive effort to study the chromosomes of all childhood solid tumours is required. We have embarked on a pilot study to obtain fresh material from most childhood solid tumours in the Northern region and carry out cytogenetic studies on these specimens. This report describes our initial results.

\section{Methods}

COLLECTION OF FRESH TUMOUR TISSUE

This was carried out in two phases. In January 1986 paediatric surgeons and pathologists within Newcastle were asked to inform us whenever a suspected tumour in a child was to be biopsied. We requested that the biopsy specimen be as generous as the surgeon could provide and be transferred fresh or in tissue culture medium (such as RPMI or Dulbecco's minimum essential medium) to a specified pathologist. A portion of the macroscopically viable tissue was transferred to the cytogenetics unit.

The second phase commenced in September 1986 
when all paediatricians within the Northern region and many of the pathologists were invited by letter to participate.

The success in obtaining fresh tumour material was assessed by comparing the number of samples received with the total number of tumours notified to the Northern region Children's Malignant Disease Registry. ${ }^{5}$

\section{CYTOGENETIC METHODS}

Tumour was dispersed by gentle pipetting to provide a cell suspension for direct and short term cultures (one to 48 hours). Long term explant cultures were established in plastic Falcon flasks using various culture media (Ham's F-10, Chang's, and Leibovitz L-15, all supplemented with $20 \%$ fetal bovine serum) and incubated at $37^{\circ} \mathrm{C}$. Colcemid exposure before harvesting varied between $0.2 \mu \mathrm{g} / \mathrm{ml}$ for 15 minutes for direct cultures and $0.01 \mu \mathrm{g} / \mathrm{ml}$ for four hours for long term cultures. Slide preparations were made by standard techniques and $G$ banded with trypsin and Leishman's stain.

\section{Results}

\section{COLLECTION OF FRESH TUMOUR TISSUE}

From January 1986 to September 1987 inclusive, 72 new solid tumours occurring in children under the age of 15 years were notified to the Northern region Children's Malignant Disease Registry. Fresh tissue, either primary or metastatic, was obtained from 39 of these 72 solid tumours (table 1). During the same period fresh tumour was obtained from eight of 10 relapsed tumours from which tissue was available and from two of four children who had a biopsy of the tumour remaining after initial chemotherapy.

\section{CYTOGENETIC ANALYSIS}

Thirty seven specimens obtained at diagnosis were assessed; analysable metaphases were obtained from 33. One patient with a neuroblastoma had a constitutional abnormality $[46, \mathrm{XX} \quad \mathrm{t}(8 ; 11)$

Table 1 Details of solid tumours presenting in the Northern region, January 1986-September 1987

\begin{tabular}{lll}
\hline & $\begin{array}{l}\text { No of } \\
\text { children }\end{array}$ & $\begin{array}{l}\text { No in which } \\
\text { fresh tumour } \\
\text { tissue obtained }\end{array}$ \\
\hline $\begin{array}{l}\text { Biopsy of primary tumour } \\
\text { Biopsy of metastatic disease } \\
\text { Biopsy of primary and } \\
\begin{array}{l}\text { metastatic tumour } \\
\text { No biopsy }\end{array}\end{array}$ & 14 & 24 \\
\hline Total & 1 & 14 \\
\hline
\end{tabular}

(q22.1;q21)]. Clonal cytogenetic abnormalities were found in nine comprising two neuroblastomas, two brain tumours, and one each of retinoblastoma, Ewing's sarcoma, Wilms' tumour, osteogenic sarcoma, and lymphoma (table 2). The remaining 23 were karyotypically normal apart from several single cell abnormalities.

Analysable metaphases were obtained from six of eight relapsed tumours studied, five of which were abnormal and both specimens obtained from second look procedures had abnormal karyotypes. Overall 16 out of 47 tumours studied had abnormal karyotypes (table 2).

\section{Discussion}

The aim of this pilot study was twofold. Firstly it was to assess the feasibility of collecting fresh viable tissue from most childhood solid tumours in the Northern region and secondly, to carry out cytogenetic analysis of the specimens. This study has shown that both aspects are feasible with the cooperation of regional paediatricians, surgeons, and pathologists. Fresh material has been obtained from most tumours, and the use of a limited number of standard techniques by a single cytogenetics department has resulted in good quality analysable metaphase preparations in most cases.

No single culture technique has so far proved superior. Further experiments may show optimal culture techniques for each tumour type. Many of the cultures showed karyotypically normal cells. These may well represent non-malignant cells, such as fibroblasts, within the tumour. We believe, however, the clonal abnormalities obtained from tumour tissue at diagnosis did originate from tumour cells. Until larger numbers have been studied we cannot be certain that some clones do not represent a secondary abnormality, occurring in a genetically unstable tumour cell, brought about and selected by the culture conditions. Particular caution is necessary in interpreting clonal abnormalities in tissues that have been subjected to chemotherapy or radiotherapy, or both.

None the less, the cytogenetic abnormalities found in cells from a heavily pretreated neuroblastoma primary tumour, ${ }^{b}$ bone marrow metastases from another, and spinal fluid seedlings from a relapsed medulloblastoma are characteristic of those in untreated tumours. ${ }^{7}$ Also two of the clones (B and C) from a relapsed ependymoma (data not in table) resemble the abnormalities described in the only other published $\mathrm{G}$ banded case of this disease. ${ }^{8}$ In all other cases, apart from the two remaining disseminated neuroblastomas, the abnormalities we have found have not previously been described. Of 
Table 2 Abnormal karyotypes from childhood solid tumours

\begin{tabular}{|c|c|c|}
\hline & $\begin{array}{l}\text { Patient status } \\
\text { at time of study }\end{array}$ & Karyotype \\
\hline Primary tumour & Long term cultures & \\
\hline Retinoblastoma & ND & $46, \mathrm{XX} / 46, \mathrm{XX} \mathrm{t}(6 ; 11)(\mathrm{p} 21.3 ; \mathrm{p} 1 ? 5 / 92, \mathrm{XXXX}$ \\
\hline Osteogenic sarcoma & ND & $46, X Y t(2 ; 3)(\mathrm{p} 13 ; \mathrm{q} 24)$ \\
\hline Ependymoma & ND & $\begin{array}{l}45, \mathrm{XY},-16, \mathrm{t}(6 ; 16) / 46, \mathrm{XY} \\
(\sim 50 \% \text { cells endoreduplicated })\end{array}$ \\
\hline Wilms' tumour & ND & $\begin{array}{l}51, \mathrm{XX},+8,+12,+12,+13,+17 \\
51, \mathrm{XX},+8,+12,+12,+13,+17, \mathrm{t}(1 ; 16)(\mathrm{p} 3 ; \mathrm{p} 22)\end{array}$ \\
\hline Wilms' tumour & PC & $46, \mathrm{XY} / 46, \mathrm{XY}, \mathrm{t}(19 ; 21) / 46, \mathrm{XY}, \mathrm{t}(10 ; 10)$ \\
\hline Neuroblastoma & PC & $46, X Y / 46, X Y, 1 p+/ 46, X Y, 1 p+, t(4 ; 10), 17 p+$ \\
\hline $\begin{array}{l}\text { Primitive neuroectodermal } \\
\text { tumour }\end{array}$ & $\mathbf{R}$ & $\begin{array}{l}46, \mathrm{XY}, \mathrm{t}(3 ; 10), \operatorname{inv}(7)(\mathrm{q} 32 ; \mathrm{p} 22) / 46, \mathrm{XY},+ \\
\text { markers including ?del (2)(q31), } \\
\text { ?t(1;18)(q1?;q21), inv(5)(q22;q23), } \\
\text { ?del(14)(q22) }\end{array}$ \\
\hline Ependymoma & $\mathbf{R}$ & 6 different clones each with multiple markers* \\
\hline Rhabdomyosarcoma & $\mathbf{R}$ & $\begin{array}{l}82, \mathrm{XX},+2,2,2,2,4,5,5,6,6,7,8,10,12,13 \\
14,15,15,18,18,19,20,21,22,22,+\mathrm{X},+\mathrm{M}_{1}, \\
\mathrm{M}_{2}, \mathrm{M}_{3}, \mathrm{M}_{5}, \mathrm{M}_{5}, \mathrm{M}_{6}, \mathrm{M}_{7}\end{array}$ \\
\hline Metastatic tumour (site) & Direct cultures & \\
\hline $\begin{array}{l}\text { T cell lymphoma } \\
\text { (pleural fluid) }\end{array}$ & ND & $\begin{array}{l}45, \mathrm{XY}+\text { multiple markers } / 87, \mathrm{XY}+ \\
\text { multiple markers }\end{array}$ \\
\hline $\begin{array}{l}\text { Ewing's sarcoma } \\
\text { (bone marrow) }\end{array}$ & ND & $\begin{array}{l}46, \mathrm{XX} / 45, \mathrm{XX},-7,-10,-21,-22,+\mathrm{M}_{1} \\
\text { ?del } 7, \mathrm{M}_{2},+\mathrm{M}_{3} \\
46, \mathrm{XX},-7,-22,+\mathrm{M}_{1},+\mathrm{M}_{2}\end{array}$ \\
\hline $\begin{array}{l}\text { Neuroblastoma } \\
\text { (bone marrow) }\end{array}$ & ND & $46, \mathrm{XX} /$ polyploids with double minutes \\
\hline $\begin{array}{l}\text { Neuroblastoma } \\
\text { (bone marrow) }\end{array}$ & ND & $46, \mathrm{XX} /$ polyploids with double minutes \\
\hline $\begin{array}{l}\text { Medulloblastoma } \\
\text { (bone marrow) }\end{array}$ & ND & $\begin{array}{l}50, X X,+5,+6,+8,+13,-11,-17,-22,+11 q, \\
+22 q,+i(17 q) / 49, X X,+5,+6,+8,-11,-17 \\
-22,+11 q+,+11 q+,+22 p+,+i(17 q)\end{array}$ \\
\hline $\begin{array}{l}\text { Medulloblastoma } \\
\text { (cerebrospinal fluid) }\end{array}$ & $\mathbf{R}$ & $46, \mathrm{XY} /$ double minutes \\
\hline $\begin{array}{l}\text { Neuroblastoma } \\
\text { (bone marrow) }\end{array}$ & $\mathbf{R}$ & $46, \mathrm{XX} /$ double minutes \\
\hline
\end{tabular}

$\mathrm{ND}=$ newly diagnosed; $\mathrm{R}=$ relapse; $\mathrm{PC}=$ postchemotherapy.

${ }^{*}$ Details of these clones are available on request.

particular interest is the primitive neuroectodermal tumour (PNET), full details of which are being published elsewhere." Potluri et al have suggested that PNETs may be subdivided by their cytogenetic features into peripheral neuroepitheliomas with a $t(11 ; 22)$ and other PNETs showing other karyotypic abnormalities. ${ }^{10}$ The tumour described here falls into the latter group.

This series of karyotypes highlights the current state of knowledge of cytogenetic abnormalities of solid tumours of childhood; each case constitutes a significant contribution to our knowledge. Although karyotypic abnormalities are being reported increasingly at international scientific meetings, most are published only as abstracts. Some patterns have begun to emerge. In retinoblastoma, isochromosome $6 \mathrm{p}$ appears to be a unique abnormality, ${ }^{11}$ and the one case of retinoblastoma in the present series also had an abnormality of chromosome 6 . Alveolar rhabdomyosarcomas are associated with $t(2 ; 13),{ }^{12}$ and evidence suggests that $3 p 14 \rightarrow 21$ may be a non-random site for change in this disease. ${ }^{13}$ In $\cong$ addition to PNETs $t(11 ; 22)$ is associated with :Ewing's sarcoma in some but not all cases. ${ }^{14}$ This association raises the possibility that Ewing's sar- $\delta$ coma and some forms of PNETs have a common origin. In translocations involving chromosome 22 의 the breakpoint arises in the region of the oncogene c-cis. ${ }^{15}$ The Ewing's tumour described in this report did not have this translocation but did have an abnormal chromosome 22 .

The association of aniridia and Wilms' tumour has $N$ been linked with constitutional deletion of $11 \mathrm{p} 13$. N Abnormalities of this chromosomal region have $\sigma$ been detected in some Wilms' tumours from children with a normal constitutional karyotype. ${ }^{16} \stackrel{0}{0}$ Additional abnormalities of chromosomes 1 and $16 \stackrel{\Phi}{\oplus}$ may occur in advanced tumours. ${ }^{16}{ }^{17}$ Recently the combination of hyperdiploidy, complex chromo- $\overline{0}$ somal translocations, and an anaplastic histological $\stackrel{\odot}{\circ}$ 
appearance of Wilms' tumour have been associated with a particularly poor prognosis. ${ }^{18}$

After leukaemias, brain tumours remain the single largest group of malignancies in children. Until recently investigation of these tumours has been hampered by problems of nomenclature and classification. Others have already begun to approach the problem of improving diagnosis and prognosis and understanding their biology by undertaking cytogenetic investigations. ${ }^{19}$

The differential diagnosis of small round cell tumours of childhood includes rhabdomyosarcoma, lymphoma, Ewing's sarcoma, and neuroectodermal tumours. Despite the increasing use of specialised investigations, including monoclonal antibodies and electron microscopy, the identity of some tumours remains obscure. ${ }^{20}$ As in haemopoietic malignancy, cytogenetic investigation of solid tumours may emerge as an important diagnostic tool. At present prognostic factors in most children with solid tumours are limited to clinical and histopathological staging and in some cases histological subtyping. ${ }^{21} 22$ Cytogenetic abnormalities may provide additional prognostic information, but until many hundreds of tumours have been karyotyped we cannot begin to approach the level of diagnostic and prognostic value that now exists for leukaemias. Despite this relative lack of knowledge, the ability to detect cytogenetic abnormalities in metastatic sites and treated primary tumours may improve the accuracy of staging procedures and assessment of response to treatment. ${ }^{6}$ This comparatively simple aspect of the value of cytogenetic investigations has so far not been exploited.

In conclusion, it is recommended that biopsy material from tumours in children should never automatically be put into formalin. The Northern region pilot study has shown that fresh biopsy material can be obtained from most childhood solid tumours and cytogenetic investigation can be successful in a wide variety of cancers. Cooperation between groups of workers in the field of paediatric oncology could lead to multicentre studies of fundamental aspects of the biology of childhood cancer, one of which is the investigation of cytogenetic abnormalities.

We thank the many surgeons, paediatricians, and pathologists who helped us obtain fresh tissue; Mrs Lorna More and the Northern region Children's Malignant Disease Registry; and Newcastle Health Authority Scientific and Research Committec and the North of England Children's Cancer Research Fund for funding this study, and Mrs Paula McEwen for secretarial help.

\section{References}

1 Rowley JD. Identification of the constant chromosome regions involved in human haematological malignant discasc. Science 1982;216:749-51.
2 Williams DL, Harber J, Murphy SB et al. Chromosomal translocations play a unique role in influencing prognosis in childhood acute lymphoblastic leukaemia. Blood 1986;68:20512.

${ }^{3}$ de Klein A, Geurts van Kessel A. Grosveld G, et al. A cellular oncogene is translocated to the Philadelphia chromosome in chronic myclocytic leukaemia. Nature 1982:300:765-7.

4 Kelin G. Specific chromosomal translocations and the genesis of $B$ cell derived tumours in mice and men. Cell 1983:32:311-5.

5 Craft AW, Amineddine HA, Scott JES, Wagget J. The Northern region Children's Malignant Disease Registry 1968 1982. Incidence and survival. $B r J$ Cancer 1987;56:853-8.

6 Bown N, Reid MM, Pearson ADJ, et al. Cytogenetic investigations in the assessment of response to treatment in neuroblastoma. J Clin Pathol 1987;40:1334-6.

7 Cowell JK. Double minutes and homogeneously staining regions: gene amplification in mammalian cell. Annu Rev Genet 1982;16:21-59.

8 Kindblom LG, Lodding P, Hajmar B, Stenman G. Metastasising myxopapillary ependymoma of the sacrococcygeal region. Acta Pathol Microbiol Immunol Scand 1986;94:79-90.

9 Bown N, Davison EV, Pearson ADJ, Malcolm AJ. Cytogenetic abnormalities in a primitive neuroectodermal tumour. Cancer Genet Cytogenet (in press).

${ }^{10}$ Potluri VR, Gilbert F, Helsen C, Helson L. Primitive neuroectodermal tumor cell lines: chromosomal analysis of five cases. Cancer Genet Cytogenet 1987;24:75-86.

1 Squire J. Isochromosome 6p, a unique chromosomal abnormality in retinoblastoma: verification by standard staining techniques, new densitometric methods and somatic cell hybridisation. Hum Genet 1984;66:446-53.

12 Seidal T, Mark J, Hagmar B, Angervall L. Alveolar rhabdomyosarcoma: a cytogenetic and correlated cytological and histological study. Acta Pathol Microbiol Immunol Scand 1982;90:345-54.

13 Trent J, Casper J, Meltzer P. Thompson F. Fogh J. Non-random chromosome alterations in rhabdomyosarcoma. Cancer Genet Cytogenet 1985:16:189-97.

14 Turc-Carel C, Philip I, Berger MP, Philip T, Lenoir GM. Chromosome study of Ewing's sarcoma (ES) cell lines. Consistency of a reciprocal translocation $\mathrm{t}(11 ; 22)(\mathrm{q} 24 ; \mathrm{q} 12)$. Cancer Genet Cytogenet 1984;12:1-19.

15 Dalla Favera R, Gallo RC, Giallonga A, Croc CM. Chromosomal localization of the human homolog $(\mathrm{C} ; \mathrm{sis})$ of the simian sarcoma virus oncogene. Science 1982;218:686-8.

${ }^{16}$ Kondo K, Chilcote RR, Maurer HS, Rowley JD. Chromosome abnormalitics in tumor cells from patients with sporadic Wilms tumor. Cancer Res 1984;44:5376-81.

17 Slater RM. The cytogenetics of Wilms' tumor. Cancer Genet Cytogenet 1986:19:37-41.

is Douglass EC, Look T. Webber B, et al. Hyperdiploidy and chromosomal rearrangements define the anaplastic variant of Wilms' tumour. J Clin Oncol 1986;4:975-81.

19 Griffin CA, Hawkins AL, Packer RJ, Rorke LB, Emanuel BS. Chromosome abnormalities in pediatric brain tumors. Cancer Res 1988:48:175-80.

20) Triche TJ, Askin FB. Neuroblastoma and the differential diagnosis of small round blue cell tumours. Hum Pathol 1983;14:569-95.

21 Beckwith JB, Palmer NF. Histopathology and prognosis of Wilms' tumours. Results from the first national Wilms' tumour study. Cancer 1978:41:1937-48.

22 Maurer HM, Donaldson M, Gehan EA. The intergroup rhabdomyosarcoma study. Natl Cancer Inst Monogr 1981;56:618 .

Correspondence to Dr ADJ Pearson, Department of Child Health, University of Newcastle upon Tyne. The Medical School, Framlington Place. Newcastle upon Tyne NE2 $4 \mathrm{HH}$.

Accepted 24 April 1988 